\title{
COMPARING JAPAN (KEIRESTU) AND KOREA (CHAEBOL) ECONOMIC EFFICIENCY ON THEIR FINANCIAL STRUCTURES
}

\author{
Dr. Rossano V. Gerald, D.B.A. \\ (International Business) Concordia Univ. San Antonio TX
}

Doi: 10.19044/elp.v1no2a8 URL:http://dx.doi.org/10.19044/elp.v1no2a8

\begin{abstract}
In this constantly changing global environment, Japan and Korea have shown impressive economic growth by creating formidable industrial powerhouse in the past two decades that carved out markets shares in the Asia, Europe, Latin and North America regions. They are known as Asia's second and third biggest economies with a real gross domestic product (GDP) in the trillions. Their economic development strategies strongly mirror each other because of an industrial group system which was foster from zaibatsu (prewar) a family owned organization that dominated the both economic activities by controlling industrial and financial policies through single parent intervention concept. After the postwar (WWII) this organization was broken up by the United States (occupier) and transformed into zeirestu and chaebol conglomerates system which were suppose to promote a more free independent enterprise system. This research paper will address how these two inter-corporate group alliances systems influence their economies strategic decision-making processes.
\end{abstract}

Keywords: Comparing Japan (Keirestu) And Korea (Chaebol)

\section{Introduction}

To understand these two dynamic economies, a person must look at their histories. Therefore, a country past social and political history influences its future economic growth and development. During the thirteenth and nineteenth centuries Korea was ruled by monarchies which supported the Korean elite groups and Imperial China's economic environment by being an agricultural supplier. This feudal state system was set up as a subculture of the Chinese culture in which the Confucian values are strictly observed in every aspect of their macroeconomic and microeconomic policies and these vertical and reciprocal personal 
obligations was also imbedded into Japanese society. (Chang, 2001) Table 1 shows those values.

TABLE 1

CONFUCIAN VALUES

- Positive attitudes to world affairs and faith in the transformability and perfectibility of
the human condition
- Importance of self-cultivation
- Lifestyle of discipline and desirability of hard work and frugality as social discipline
- Duty; consciousness in the form of reciprocity of respect and authority and public
accountability
- Centrality of overriding concern for the family in social harmony and stability
- Political order as a moral community
- Necessity of government leadership
- Disinclination for civil litigation

Source: Kim, 1994.

In the late 1800s, the Treaty of Khangwa was signed by Japan and Korea in which allowed trade commerce throughout Korea's ports, but by the beginning of the twenty century Japan's military might conquer the Korea peninsula and made it a colony. Some economists believe that Japan colonialism of Korea led to the "modernization" of this region. For example, "Japanese occupation destroyed the class system, abolished slavery, broke up the great estates and paved the way for land reform. It led to increase education for the average Korean, the transfer of managerial skills in industry and commerce to Korean and the creation of an urban industrial workforce.” (Kennett, 2004, p.313). This colonial system was a sponsorship of the Japan's government and the zaibatsu diversified industrial groups which were elite policymakers and business families that controlled most economic activity in this country; and this same top-down, hierarchical structure was implemented into every colonial province to control their economic and political systems. For instance, the colonial government passed legislation that allowed complete controlled over Korean industrial sectors and business groups was formed only to serve colonial ruler interests. "These colonial rulers introduced the Company Law in 1911 requiring Korean entrepreneurs to get permission from the colonial government before setting up industrial firms." (Cha, 2004, p.281) This business law created indigenous capitalists' state that produced goods and products for the Japanese industry business, which already controlled over 70 percent of Korea capital. Although, in the 1930s, the Japanese government did implement a heavy industrialization plan for the region, its intention was not foster economic growth, but instead to use this industrial base as launching 
pad for an invasion into China, Taiwan and other Asian countries. As a result, some economists are saying that the zaibatsus' nationalist policy that ties them with industry and state was partly responsible for Japanese military adventurism in Asian Pacific regions, which led to World War II. Fortunately, after the war the zaibatsu system was broken up by occupier the United States (U.S.) both in Japan and Korea, which led to a more independence equity shareholders such as the keiretsu and chaebol industrial groups.

Founders; what business role does these new industrial groups play in controlling their nation equity capital?

As previous mention, the development of the keirestu and chaebol groups was brought about by U.S. dissolving the former zaibatsu (prewar industrial groups) that dominated Japan and Korea's economic and political activities. According to Ming and Lai (1999) "keiretsu is an organizational arrangement created for a group of companies or conglomerates. However, many researchers and businesspersons use this term loosely to mean business groups that use keiretsu as a device to systematically arrange or organize relationships among companies." ( p.424). True of the matter, "the member companies of the Japanese keirestu are bound by the cross-holding of stock which consists of a small percentage of shares and a great degree of personnel interaction due to the exchange of the board of directors as well as employees between member companies. Since these companies are strongly linked to each other, they share common goals which are carried out by business strategies formed jointly by the top executives of all the members companies." (Putnam \& Chan, 1998, p.113). "These business leaders are divided into six separate groups that are comprised of most of the largest corporations in Japan including the largest commercial banks. Each of the six respectively is linked together by shareholding interlocks and by ties of trade and credit and the largest members of each are represented in the six respective monthly "presidents' council" meetings." (Flath, 1993, p.249)

To sum it up, "the term keiretsu may be more comprehensively defined as follows: 1) a systematized arrangement for internal control of member firms; 2) a means of control supported by a combination of commercial justifications (including legal ties, financial ties, and operational ties) and emotional commitments (including personal ties and cultural bonds); 3) a mechanism to facilitate policy implementation; 4) not only the effects are observed and reinforced by group members' cooperative activities but the pattern of relationships is sanctioned by a symbiotic relationship between major Japanese business groups and government bureaucrats." (Ming \& Lai, 1999, p.428)

"The chaebol were family founded, owned and controlled, with a plethora of diverse subsidiaries linked in opaque fashion. Their Korean 
nickname, octopus with many tentacles' is indicative of this. They were held together by cross share-holdings, subsidies and loan guarantees with intergroup competitive tension, distrust and rivalry. Their all-powerful founding chairmen, on the other hand they were not de jure legally liable for company misfortune as they did not actually hold formal positions." (Richter, 2002). As the figure 2 shows that majority original founders still owns most of the equity capital. This is because many of the wholly owned use a high debt-toequity ratios system that allows small equity capital to be owned large amount of assets.

P. Bongini, G. Ferri and H. Hahm/The Financial Review 35 (2000) $31-50 \quad 41$

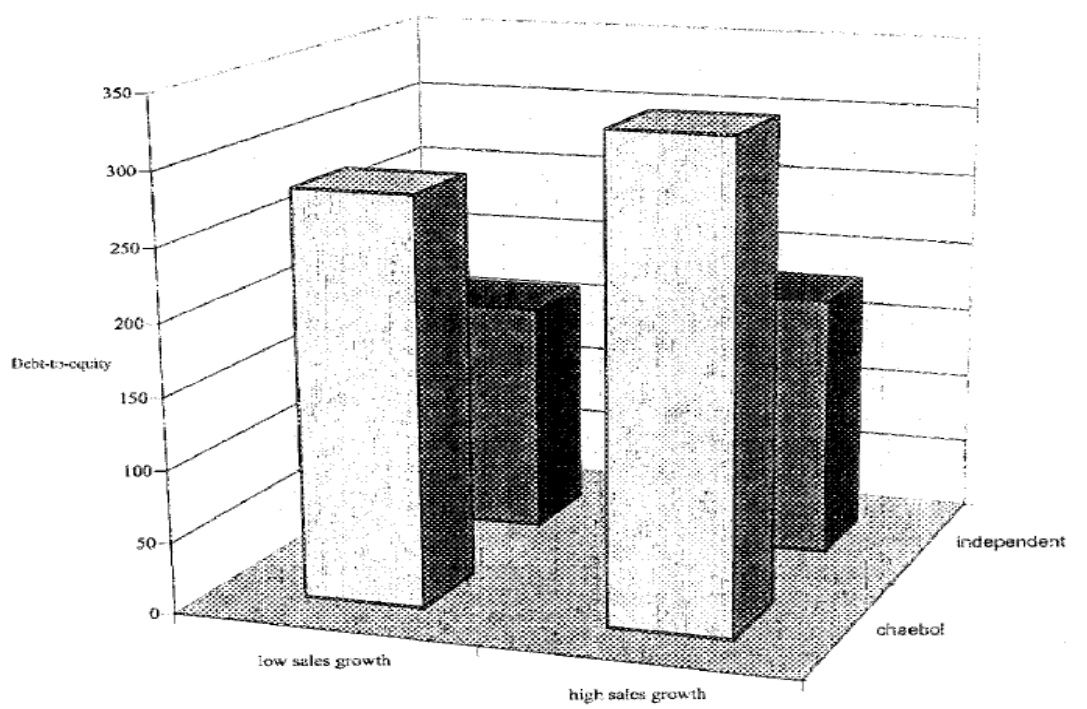

Figure 2

Deht-to-eguity ratio as a function of sales growth and corporate governance

Figure 2 presents the average debt-to-equity ratio (in percentage on the $z$-axis) for low sales growth and high sales growth firms (breakdown on the $x$-axis) according to whether they belong to a chaebol or are independent (breakdown on the $y$-axis).

But, this high ratio of debt to equity also means that any failure in manufacturing could result in dire consequences for the banking system." (Kennett, 2004, p.323). Also, "the chairman controls the company with absolute power and has no tenure limit. The chairman's power is all encompassing, and his directive and even whims must be executed immediately. The chairman is the absolute power for many chaebols." (Lee, 2003, p.11) Table and figure shows those challenges chaebols faces and internal ownership of the industrial groups within the past three years. 


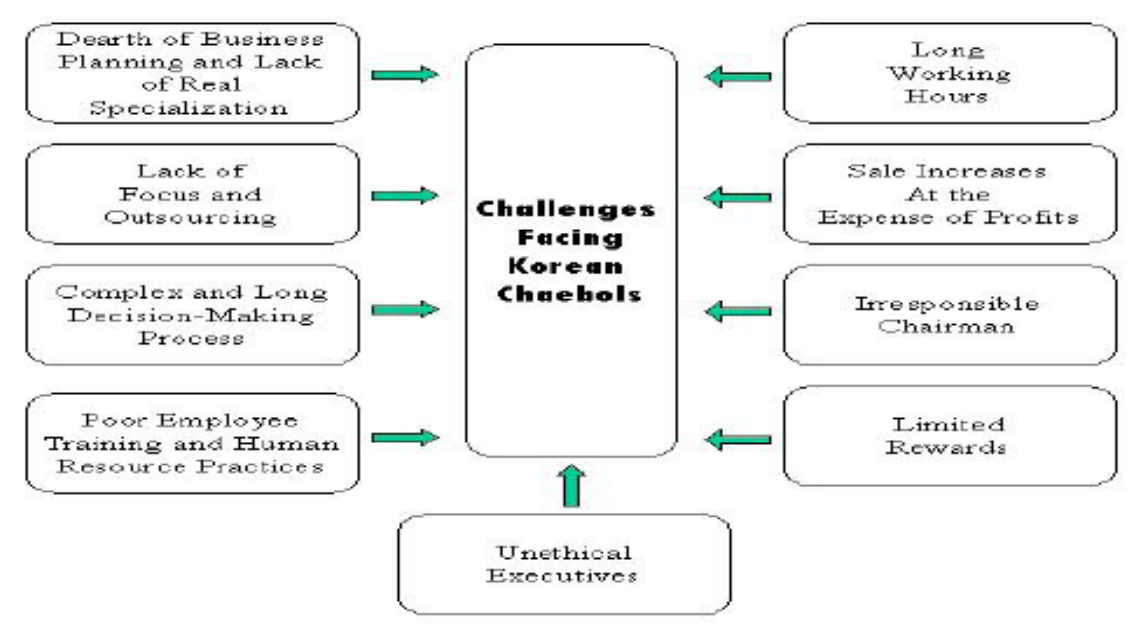

Table 8 Internal Ownership of the 10 Largest Business Groups. Jotal• •

\begin{tabular}{|c|r|r|r|r|}
\hline \multicolumn{1}{|c|}{ Ownership } & \multicolumn{1}{|c|}{2000} & \multicolumn{1}{c|}{2001} & \multicolumn{1}{c|}{2002} & \multicolumn{1}{c|}{2002} \\
\hline Chaebol head and family & 11.30 & 8.97 & 8.64 & 8.72 \\
\hline Affiliated companies & 31.46 & 32.35 & 32.91 & 32.27 \\
\hline Corporate equity shares & 3.84 & 4.65 & 4.27 & 3.93 \\
\hline Total & 46.60 & 45.97 & 45.82 & 44.92 \\
\hline
\end{tabular}

Source: Korea Stock Exchange (2004b).

However "the chaebol group founders have survived and expanded by using their entrepreneurial skills. First, they have developed clear-cut visions for their businesses. Then, they implemented their visions through carefully prepared plans. Second, they have been successful in political manipulation, an extremely important item in South Korea. They have convinced the government and political leaders that their ideas and plans for their businesses will help the economy's expansion. Third, they are aggressive. They created new corporations, added new product lines, bought and merged with existing corporations and challenges competition vigorously in both the domestic and international markets. Fourth, the founders and leaders of the chaebols groups are effective managers. Most top executives, including the founders of the present chaebols groups, are goods managers in that they make good decisions either through their own insight or with the help of their inner circles." (Chang, 2001) 
As a result, this corporate structure influences the corporate governance and its relationship with the government. According to Kennett (2004), "Korean the decision making process is more unilateral, flowing from government to industry. In Japan "the iron triangle" worked more cooperatively and ideas flowed in both directions." (p.322) However, some economists believe that keirestu and chaebol's decision making process leads to corruption in all aspect of the business and bureaucratic systems. In recent studies researchers had found that unethical behavior between these nations' bureaucrats and businesspeople was wrecking their economic system.

\section{Government and Corporate Governance}

What role does government plays influencing the corporate governance in these groups?

The phrase: "dango mentality" is use to describe the interlinked types of collusion within Asian politics and industry. Also, the "Dango Tango" is other phrase that is use to capture the intimate, interconnected nature of the partnership among the "iron triangle" of Japanese politics: businessmen, bureaucrats and politicians." (Black, 2004 p.606). This collusion relationship means that government and political leaders can manipulate the marketplace and thus create corrupted businesses environment. Therefore, dango mentality can influence corporate governance policy within both industrial groups. Corporate governance is the relationship among the many business players such as shareholders or owners, and regulators; and includes their corporations' transparency or lack of it when dealing accounting, auditing and disclosure practices. For example, "Japan and Korea, banks have found it difficult to extract themselves from the tight binding of the industrial groups and political networks that pressure them to lend chosen companies or industries or to allow these borrowers to effectively default on loans at low point their business cycle, thus creating corrupted environment that prevent good governance structures." (Rose)

Therefore, the omnipotent power of the conglomerates indicates that bankers or (owners) plays meaningful role corporate governance, because they have ability to influence economic development in their region. As a result, industrial conglomerates (keirestu and chaebol) are major problem in their nations banking system. Also, poor corporate governance practices affect core groups (horizontal or vertical) activities, because they are financially linked to the industrial groups.

\section{Horizontal and vertically oriented}

How does core groups affects the financial sectors?

According to Kennett (2004), "chaebol conduct an even wider range of activities than keirestu. Many keirestu are vertically oriented (like 
Toyota) and although the group consists of many firms, all are oriented around a core activity. Even the horizontal keirestu, which are diversified, tend in general to be more closely grouped around core activities than the chaebol."(p.322). "Vertical integration increases the size of an organization which results in additional hierarchical levels and greater centralization." (Dryer, 1996, p.653). However, "one of the obvious differences between the horizontal and vertical types is the pattern of stockholding. Multiple mutual stockholding is common among members in a horizontal keirestu. Because every member is a major or minor stockholder of the others, and sometimes has representatives as directors of the other members' board of directors, mutual respect and consideration are not only important but also necessary." (Ming \& Lai, 1999, p.429). Figure 1 shows the difference between horizontal and vertical oriented system.

\section{Figure 1}

\section{Organizational Structure of Horizontal KBG and Vertical KBG}
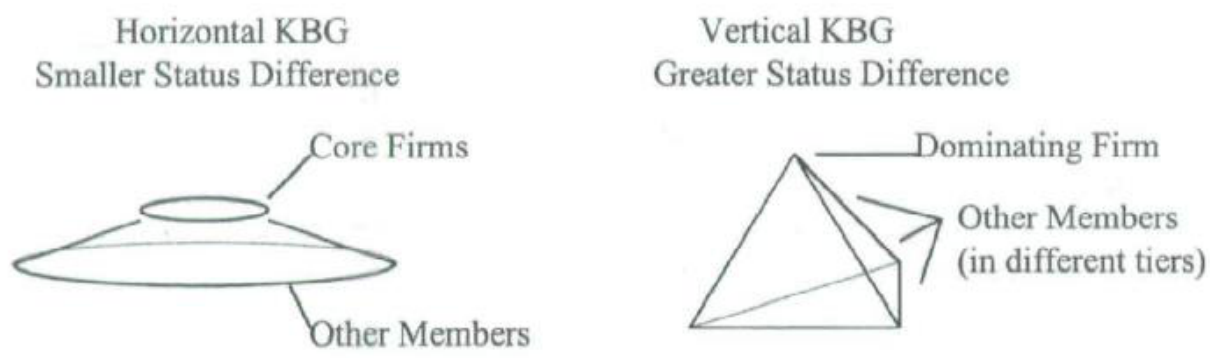

The Japanese keiretsu and chaebol conglomerates are financially powerful due to their relationships with in-house or non in-house financial institutions. For example, keirestu conglomerates are organized around main financial institutions and trading companies that foster and finance their projects. As a result, "main bank plays an important role in the provision of corporate finance and the provision of corporate governance." (Matsuura et al 1985,) However, the chaebol conglomerates are under central banking system that remains under government controlled, which leads to bureaucratic management (poor horizontal) system that favors "big four" companies which controls most of the exports and foreign investment in this economy. Despite the difference between core groups oriented process both countries' financial sectors needs restructuring, because of their weak loan practices and over-regulated banking system. This is due to bureaucratic intervention that allows bad loans to be opened with dummy names (chaebol) and to corporations who could not repay their bad loans (keirestu) which led to corruption in their financial systems. 


\section{Financial Institutions}

What effects do these industrial groups have over their banks?

For instance, "Korean companies remain plagued by adverse publicity, bankruptcy, state bail-out and opaque operations. High profile examples include Daewoos' huge debts and accounting fraud, Ford abandonment of interest in Daewoo Motor (after 6 months) in September 2000 followed by inordinately long subsequent negotiations with GM (in 2002)." (Rowley \& Bae, 2004, p.314). Also, "the corporate debt of the top 28 chaebols reached 247 trillion won at the end of 1997, with the average debt - equity ratio reaching $449 \%$ per firm. The figure for nonperforming loans of banks provided by the Financial Supervisory Commission (FSC) stood at 87.26 trillion on ( $\$ 63$ billion) at the end of March 1998." (Yong Ahn, 2001, p.453). Table 5 shows the average debt-equity ratios between Japan, and Korea during the 1990s.

Table 5. Korea-International Comparison of Average Debt-Equity Ratios in the Manufacturing Sector (In percent)

\begin{tabular}{|c|c|c|c|c|c|}
\hline \multirow[b]{2}{*}{ Year } & \multicolumn{2}{|c|}{ Korean } & \multirow[b]{2}{*}{ United States } & \multirow[b]{2}{*}{ Japan } & \multirow{2}{*}{$\begin{array}{r}\text { Taiwan Pro } \\
\text { of Chi }\end{array}$} \\
\hline & Manufacturing & 30 chaebols $1 /$ & & & \\
\hline 1991 & 307 & 403 & 147 & 209 & 98 \\
\hline 1992 & 319 & 426 & 168 & 202 & 93 \\
\hline 1993 & 295 & 398 & 175 & 202 & 88 \\
\hline 1994 & 303 & 403 & 167 & 196 & 87 \\
\hline 1995 & 287 & 388 & 160 & 196 & 86 \\
\hline 1996 & 317 & 450 & 154 & 187 & .. \\
\hline
\end{tabular}

Sources: Fair Trade Commission; Financial Statements Analysis, Bank of Korea; U.S.Census Bureau

Quarterly Financial Report for Manufacturing, Mining, and Trade Corporations; and The Quarterly

Report of Enterprises, Ministry of Finance, Japan

Quoted from Republic of Korea: Selected Issues, Jeanne Gobat, 1998, IMF Staff Country Report

1 / Nonfinancial subsidiaries of 30 largest chaebols.

However, Japan's financial institutions are also pled with the same financial woes. For example, "The pillars of the keirestu and the main bank system began to crumble; in 2003, most of the large banks' efforts to clean up their books had proven futile, forcing the government to purchase bank shares on a large scale to enable banks to stay in business and maintain the $8 \%$ BIS capital adequacy ratio. As a result, some of Japan's leading banks are now owned to varying degrees by the government. (Scheade, 2000, p.286) These corporate bankruptcies should blame on the dango concept that allowed the collusion of businessmen, bureaucrats and politicians with the country financial institutions which induced bankruptcy behavior in this 
industrial groups system. This led to financial distress because firms were unable to meet their obligations and defaulted on their notes and loans. Thus bankruptcies usually entail substantial poor corporate governance, because core groups' refusal to honor their debts. As a result, "until substantial corporate restructuring is achieved, the Japanese and Korean financial sectors will continued to be weak." (Kennett, 2004, p.337). Figure 1 shows Japan bankruptcies issues during past two decades.

Figure 1: Bankruptcies in Japan between 1987 and 2003

(Key: gray block = number of bankruptcies; black bar = liabilities)

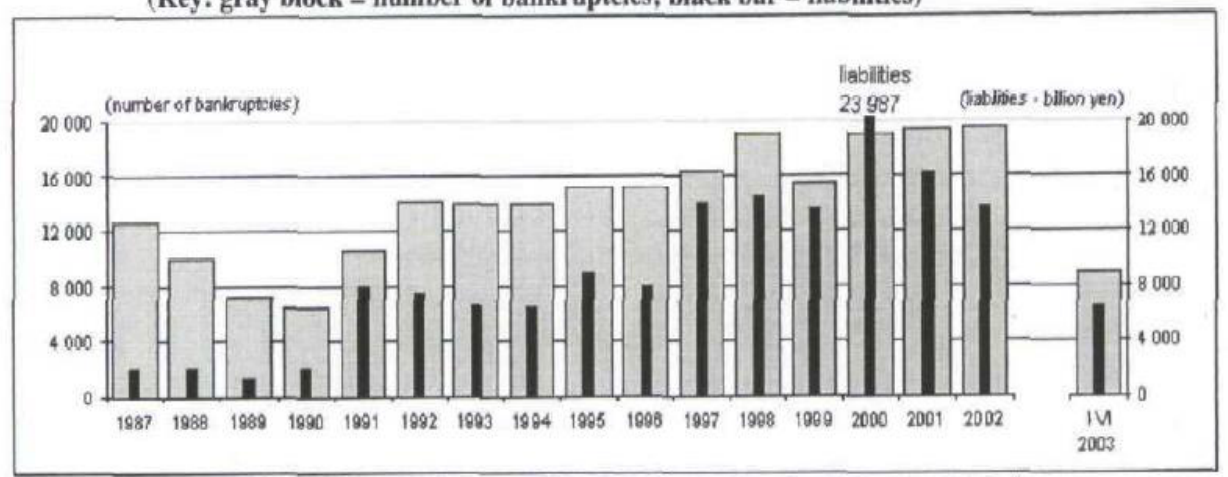

Source: Data from Teikoku Databank, Ltd. 1998-2003 data retrieved on 5 October 2003 from http://www.tdb.co.jp; 1987-1997 data retrieved on 10 October 2003 from

http://www.jei.org/Archive/JEIR98/9804w3.html. Teikoku Databank data indicates a greater number and severity of bkruptcies than does comparable data from the Bank of Japan.

\section{Deregulation and the Bad Loans Problem.}

Both nations' financial sectors were under government direction promoted core groups as source for future growth and development, the government played an important role as a co-coordinator in the intra-groups cross investment system that guaranteed loans to chaebol or keirestu groups. Therefore, if these economies want to have long-term economic growth, they must pass legislations that will deregulate and revitalize their financial sectors. Also, senior bureaucrats in both countries need to understand that the dango system is harming their economies, because it breeds corruption in every aspect of business and financial sectors. "Corruption is the primary barrier to reform in Japan and Korea. In short, ethical norms that legitimized cartels and incestuous ties between senior bureaucrats, politicians and industry leaders have led to the wrecking of the Japanese or Korean economic miracle. The problem is ethical and the solution should be ethics and pragmatism. (Black, 2004,p.619). Therefore, chaebol group must understand that they are the product of the governmentindustry relationship which means that their business success depends mostly on intra-groups cross investment practices; and keiretsu group business success also is effective by the bureaucratic and political supports that is funneled through the Ministry of International Trade (MITI), the Ministry of 
Finance (MOF), and the Bank of Japan (BOJ). Therefore, financial reform is needed in both economies, because it affects their banks borrowing and lending procedures. "Thus government must revise or introduced various laws to push conglomerates (keirestu and chaebol) in the direction of improving corporate governance, capital structure and redirection of business focus, with less diversification and concentration on core competence areas." (Rowley \& Bae, 2004)

\section{Summary}

This study revealed that favored keirestu and chaebol groups are favored by government agencies that provides financial support these core groups regards of their bankruptcies woes. Also, it revealed that a long-term corporate governance reform is needed to ensure business transparency activities and eliminate lending without prudential rules in this international financial environment which can improve capital structure by holding shareholders and management accountable for their financial transactions. Because both nations economies are influenced by this "clique-like patterns based on alliances" (dango) and incentive for corporate governance reform is needed to help created healthier corporate sector that will increase their global confidence.

\section{Future research recommendation}

Future research needs to be conducted how the keirestu or chaebol groups' concept can be used in other developed or developing countries heavy industrial sectors. For instance, "the Japanese keiretsu concept is embraced by American multinational corporations such as Chrysler and Ford. The successes of companies like Chrysler in developing organizational structural similar to those of dominant central firms in Japanese keiretsus can be seen as an inspiration to American companies which are striving to succeed in the global economy." (Putnam \& Chan, 1998, p.199). But, the question is would Chrysler and Ford keirestu concept be stifle by government and financial regulator policies?

\section{References:}

Ahn, C. Y. (2001). Financial and corporate sector restructuring in South Korea: Accomplishment and unfinished agenda. The Japanese Economic Review, 52(4), pp.452-470.

Black, W. K. (2004). The Dango Tango: Why corruption blocks real reform in Japan. Business Ethics Quarterly, 14(4), pp.603-623.

Cha, M. S. (2004). Facts and myths about Korea's economic past. Australian Economic History Review, 44(3), pp.278-293. 
Chang, C. S. (2001). Chaebol: The South Korean Conglomerates. Business Horizons, , pp.51-57.

Dyer, J. H. (1996). Does governance matter? Keirestu alliance and asset specificity as sources of Japanese competitive advantage. Organization Science, 7(6), pp.649-666.

Flath, D. (1993). Shareholding in the Keirestu, Japan's financial groups. The Review of Economic and Statistic, , pp.249-257.

Kennett, D. (2004). Comparative Economies (2nd Ed.). 5191 Natorp Boulevard, Mason, Ohio 45040: Thomson: South-Western.

Lee, S. (2003). South Korea: From the land of morning calm to ICT hotbed. Academy of Management Executive, 17(2), pp.7-18.

Matsuura, K., Pollitt, M., Takada, R., \& Tanaka, S. (2003). Institutional restructuring in the Japanese Economy since 1985. Journal of Economic Issues, 37(4), pp.999-1022.

Ming, G., \& Lai, H. (1999). Knowing who you are doing business with in Japan: A managerial view of Keirestu and Keirestu Business Groups. Journal of World Business, , pp.423-448.

Putman, L., \& Chan, P. S. (1998). The American Keirestu: America's new competitive advantage. American Business Review, , pp.113-119.

Richter, F. J. (2002). Redesigning Asian Business in the Aftermath of the Crisis. Westport, CT:Quorum, , .

Rose, J. (2004). The state of corporate governance in Asia - risks and opportunities for investors and companies. Retrieved June 20, 2006, from www.economist.com/agenda/displaystory.cfm?story_id3468844

Rowley, C., \& Bae, J. (2004). Big business in South Korea: The reconfiguration process. Asia Pacific Business Review, 10(3/4), pp.302-323.

Schaede, U. (2004). What happened to the Japanese model?. Review of International Economic, 12(2), pp.277-294. 